\title{
Revitalisation Strategies of Urban Public Space in George Town World Heritage Site
}

\author{
Maimunah Ramlee 1 , Dasimah Omar², \\ Rozyah Mohd Yunus², Zalina Samadi2 \\ ${ }^{1}$ Faculty of Architecture, Planning and Surveying, \\ Universiti Teknologi MARA Cawangan Perak Kampus Seri Iskandar, Malaysia \\ ${ }^{2}$ Faculty of Architecture, Planning \& Surveying, \\ Universiti Teknologi MARA Kampus Puncak Alam, Selangor, Malaysia \\ maimunahramlee@gmail.com, dasimaho@yahoo.com, \\ rodzy859@salam.uitm.edu.my, zalin628@salam.uitm.edu.my
}

\begin{abstract}
Revitalisation of urban public space in Core Zone, George Town World Heritage Site (GTWHS) is a mechanism to redevelop the public space area in accordance with the development growth and population. This paper has discussed the revitalisation factors in creating a great urban public space. The main objectives of this study are : 1) to identify urban public space characteristics which is significantly for revitalisation purposes, and 2) to derive the more functionally public space that fit the modern urban life. A combination of method was applied, including quantitative and qualitative method. It has been concluded that it is important to revitalise urban public space through planning and urban management.
\end{abstract}

Keywords: public space; urban revitalisation; revitalisation strategies

eISSN 2514-751X @ 2019. The Authors. Published for AMER ABRA cE-Bs by e-International Publishing House, Ltd., UK. This is an open-access article under the CC BY-NC-ND license (http:///creativecommons.org/licenses/bync-nd/4.0). Peer-review under responsibility of AMER (Association of Malaysian Environment-Behaviour Researchers), ABRA (Association of Behavioural Researchers on Asians) and CE-Bs (Centre for EnvironmentBehaviour Studies), Faculty of Architecture, Planning \& Surveying, Universiti Teknologi MARA, Malaysia.

https://doi.org/10.21834/aje-bs.v4i12.339 


\subsection{Introduction}

The urban revitalization has been highlighted in the industrialized nation after the World War II (Farzaneh, 2011). As noted by Couch, Sykes and Borstinghaus (2010), this impacted particularly in Western Europe and United States which experiences with the issues from the war that leads to the social problems, economic change and environmental degradation. On the other hand, Abdul Majeed (2012, p. 113), suggested that "rapid urbanization requires cities to be made livable and sustainable to optimize the potential of cities as the engines of economic growth". Therefore, this is important to highlight the urban revitalization concept in supporting redevelopment of city centre.

Looking at the urbanization and rapid development in Malaysia, public space become important components in urban areas and play a major role in community life particularly in social development. This coincides with physical character of the public space that allows peoples regardless of different background to visit public space. Public space need to be serve for social activities and events as well as gathering place. In addition, the nature of public space also need to be attractive so that people can enjoy the life. Public spaces are the necessary components of the city from the diversity point of view. The study from Rostami, Lamit, Khoshnava and Rostami (2016) support the positive functional of public space in terms of local environment quality, physical and ecological roles as well as leads to the positive correlation between mental and psychological health of human beings.

Revitalization is substantially important strategy which are aimed at the coinciding adaptation with urban public space in GTWHS. Therefore, regarding the views and definition on the public space, it will fulfils the users' need in urban area with different functions and features. Yet, reminds us to think that revitalization strategies can create successful public space that bring the enjoyment and pleasant to the individuals and families.

Coinciding with the importance of public space role and function, this paper has determine the objectives to identify the urban public space characteristics which could effectively be supported for the revitalization purposes, and through what medium to produce the fuctionally and successful public space with positive value and influence on modern urban life.

\subsection{Literature Review}

Kurniawati (2012), argued that sometimes public space can be interpreted as a gathering space. In this situation, the public space determination is closely related to the social capital in participation of empowered people in revitalization strategies(Zhai\& $\mathrm{Ng}, 2013$ ). In addition, several studies described the public space as a place for social interaction, connection and engagement which reflect numerous obstacles, challenge and problems of its users (Sakip, Mt Akhir \& Omar, 2015; Rostami et al., 2016). Following this review, Qamaruz-Zaman, Samadi and Nik Azhari (2013) stated that public space become more attractive and livable through social activities in promoting social engagement and interaction which accessible from all sorts of users background as well as provided with various activities and functions. Conceptual framework outlined as a guide in conducting this study and as shown in Figure 
1.

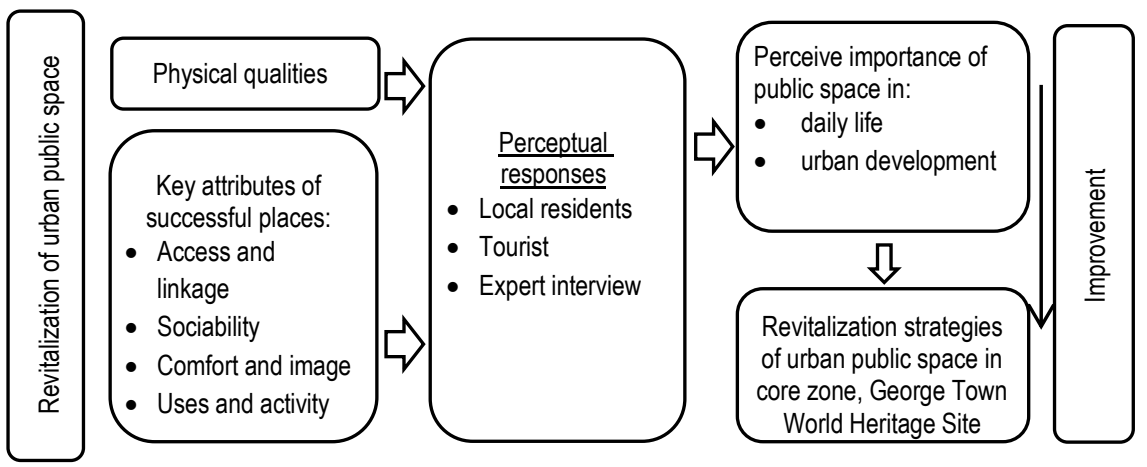

Figure 1: Conceptual framework of the study

Based on Figure 1, the important aspect of a place is the physical qualities which can contribute to the characterisrics of place and create sense of place (Kusumowidagdo, Sachari \& Widodo, 2015). As Doratli, Hoskara and Fasli (2004) presented, the places surrounded with high qualities and values are become worthy to be revitalized and it is fit with the location of study area in core zone George Town World Heritage Site. Besides, this study emphasizing the four key qualities such as activities, comfortable accessible and sociability in determining public space as successful place that outlined by Project for Public Spaces [PPS] and Metropolitan Planning Council [MPC], (2008). In addition, expert interview and survey questionnaire were conducted as peoples' perceptual responses. Consequently, it is an important method in contributing revitalisation strategies of urban public space.

Negative impact of the rapid commercial development which involve the development of public space in historic sites and urban areas in Malaysia has attracted much controversies for its preservation. As stated by Samadi and Yunus (2012, p. 343) the revitalization of heritage area has risen from "the issue of generalization due globalization in the early decade of the millennium". Usually, the value of public space in historic area has been highlighted and use as landmark which is marked as substantial identity in historic site. Thus, revitalization strategies should take due consideration of the development impact in historic cities in order to adapt better strategies towards successfull public space within the existing heritage areas.

According to Bagwell, Evans, Witting and Worpole (2012) revitalization startegies of urban public space had been proposed to engage intercultural communities together. Consequently, in this study there are several aspects shoud be highlighted in generating revitalization strategies. Furthermore Ja'afar, Sulaiman and Shamsuddin (2012)argued that physical factor as the aspect that plays an important role in contributing public space characteristics in order to reflect the use and behaviour pattern. The study area is a suitable heritage site, which make it worthy qualities and valueable of revitalization whereby the place has became an asset of heritage cities. Therefore, as acknowledged by Project for Public 
Spaces [PPS] and Metropolitan Planning Council [MPC], (2008), this study only focused on key attributes of the successful places to achieve research aim, they are:

Sociability

Access and linkage

Comfort and image

Uses and activity

Abdul Rahman, Shamsuddin and Ghani (2015), stated that comfortable and lively environment for the users are important and closely related to human comfort or well-being in carrying out activities at public spaces. This is supported by Samadi and Yunus (2011) argued that in achieving human comfort at public space, the landscape elements should be highlighted as physical attributes of revitalization strategies. According to Bagwell et al., (2012) the physical setting closely related to the planning, designing, implementing and managing of the urban public spaces landscape especially for comfort, safety and enjoyment of users as well as having a huge symbolic and aesthetic dimension. Moreover, Nasution and Zahrah (2012) explained that the perception and satisfaction of human needs interconnected to the good quality of urban space. Thus, this study requires data and information on users' needs an perceptions which make it very important and useful for further improvement of public space. In addition, Nasution and Zahrah (2015) noted that preferences and perceptions of users may assist and help in understanding the users' needs in order to better improve public space.

It is clear that the revitalizing of urban public space approach is commendable, however, the significant change in urban revitalization should be inspired to maintain the heritage value in historic cities. In achieving this, the successful public space in the historic site should consider users' preferences as well as must be an integral part of the urban revitalization in collaboration the effective role of the government and stakeholders in the design and implementation of the policy (Said, Aksah \& Ismail, 2013).

\subsection{Methodology}

In achieving the aim, this study applied a mixed-method approach whereby qualitative and quantitative research methods are combined to generate better understanding of a study. The qualitative method is based on the site observation, literature review and in-depth interviews. While, the quantitative method involves questionnaire survey by the assessments on local residents and tourists regarding successful factors of public spaces. The case study selected was Padang Kota Lama which covers the urban public space in Core Zone George Town Word Heritage Site.

Initially, the preliminary study focused on the concept of revitalization of urban public space and related variables through literature review. Subsequently, site observation was conducted pertaining to the physical condition and attributes of study area. The in-depth interview was conducted for the following step that involved five respondents consisted of experts in related fields of this study. The data was recorded and transcribed through content 
analysis. In addition, the expert interview was to get better understanding of study and deeper views on certain subjects. The study conducted the primary data collection of the site through field survey. The survey method consists of three stages, namely, questionnaire design, the survey sampling and data collection. In determining the sample size for the field survey, a convenience method of non-probability sampling technique was applied in this study. In order to determine local residents and tourists perceptions and opinions related to this study, a self-administered survey was conducted for 400 samples of questionnaire amongst local residents and 100 samples questionnaire amongst tourists at public space in George Town World Heritage Site. The questionnaire survey consisted of closed-ended questions, numeric questions and Likert Scale.

In conducted this research, the limitation of the study had been highlighted. The selected study area is based on the typologies of urban public space within GTWHS.

\subsection{Study area}

The study area is Padang Kota Lama which is located in Core Zone, George Town World Heritage Site (GTWHS), Pulau Pinang. The historical site and waterfront area are located in the study area and serves as uban park area which has been inscribed by UNESCO. In addition, the study area functions as a main recreational and social centre in the evening and weekends especially for the local ressidents as well as an ideal place for relax and gathering place with family in Pulau Pinang. The panoramic view and entrance to Padang Kota Lama as shown in Figure 2 (a) and (b). Besides, the relationship between the social activities and public space in heritage site being as the focus point and attraction area for visitors in carrying out the daily activities such as sepak takraw and basketball game beside the Fort Cornwallis, busking and fishing at promenade walkways. This is supported by Hajmirsadegh, Shamsuddin and Faroughi (2012), stated that the physical attributes of public space such as the devices and facilities should be provided for the daily requirements of visitors.

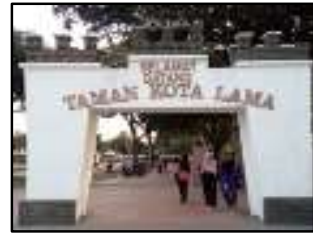

(a)

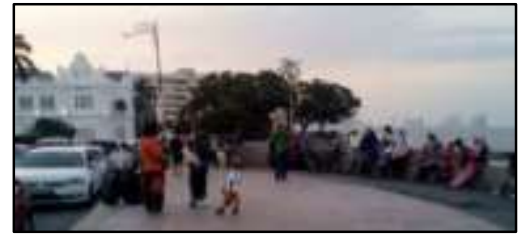

(b)

Figure 2: (a) Entrance to Padang Kota Lama; (b) Panoramic view of Padang Kota Lama

There are historic buildings within the study area in core zone GTWHS aligned on three main streets of Lebuh Light, Jalan Padang Kota Lama and Jalan Tun Syed Sheh Barakbah. Historic and prominent buildings around this study area are Town Hall, Esplanade, City Hall, Fort Cornwallis, and Cenotaph. Throughout the study area, facilities and public spaces are interconnected physically and socially especially for social activities. Presence of functional public space is complementing the activities, such as children playground, promenade 
walkway, food court, basketball court and benches. Figure 3 shows the activities at the urban park which also serve as a venue for celebrations, events, urban activities and cultural festivals such as Penang Bon Odori Festival.
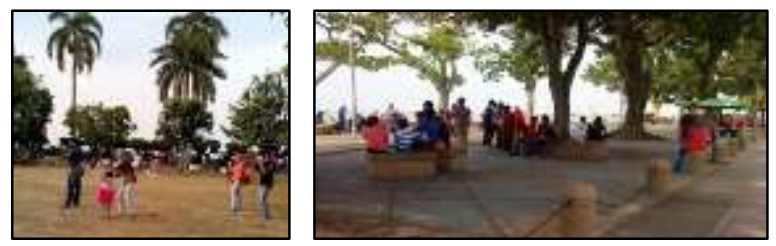

Figure 3: Users with their activities in Padang Kota Lama

\subsection{Results and Discussions}

The study employed SPSS Software for data analysis of questionnaire survey. In this study, the demographic, behavioral pattern and respondents' perceptions were analysed from the questionnaire survey. The intrepretation of urban public space characteristics in heritage site towards each variable had been the focus for the analysis intended to add another layer of understanding the public space revitalization strategies. However, the purpose and interest of people coming to study area were determined through the analysis of additional attributes from the respondents' profile such as gender, race, age group and home distance to public space. Simultaneously, the content analysis was adopted for qualitative analysis which was based on the interview questions responses from the government officials and NonGovernmental Organization members.

\subsection{Urban public space in daily life}

The users of public space need to perceive that the recreation activities by themselves at public space could benefit to health, social interaction and economic value (Nasutionet al., 2015). In this regard, the public participation in this study is very important to contribute beneficial public space settings. Hence, the primary focus is the involvement of community or public space users in this study. Public space should ideally enable people to carry out their passive and active activities in their daily life. Likewise, social interaction are mostly generated by various activities at public space which will create experience to the users. In addition, urban public space becomes a vital part of urban life and has significant impact on economic growth in urban area.

According to Namin, Najafpour and Lamit (2013), the physical aspect of public space being interconnected by all elements in public space which often having node of activites. From the analysis, the purpose of visiting the study area as shown in Table 1 above. Following this, the place setting that foster good social interaction are closely related to the active and passive activities at urban public space, such as public space provides pleasant environment as a place for relaxing, jogging and sitting area; children playing with their families; and create informal communication space. Besides, this outcome is supported by 
in-depth interviews, whereby the study area is familiar and well-known urban park amongst local residents in Pulau Pinang and tourists in GTWHS as well as hosts the yearly, monthly and weekly events. Thus it is important to ensure that public space should be well-equipped with proper and suitable facilities simultaneously connected between users and place as well as contributing attractive, harmonious and clean environment in their daily life.

Table 1: Descriptive analysis on purpose of visit

\begin{tabular}{llll}
\hline & Minimum & Maximum & Mean \\
\hline Relax & 2 & 5 & 4.2500 \\
Walk & 1 & 5 & 4.1400 \\
Outdoor activities & 1 & 5 & 3.9575 \\
Exercise & 1 & 5 & 3.4725 \\
Talking with & 1 & 5 & 3.7800 \\
friends & & & \\
For fresh air & 1 & 5 & 4.2800 \\
Have fun & 1 & 5 & 4.1225 \\
Making friends & 1 & 5 & 2.4975 \\
Doing nothing & 1 & 5 & 2.2100 \\
Getting & 1 & 5 & 2.5950 \\
information & & & \\
Escape from & 1 & 5 & 1.1275 \\
home & & & \\
Dating & 1 & 5 & 3.0450 \\
View city scenery & 1 & 5 & 3.8950 \\
Play with child & 1 & 5 & 3.1650 \\
\hline
\end{tabular}

\subsection{Public space and urban development}

Currently, urban development in Malaysia is highlighting the public space whereby it is becoming a major concern and interesting phenomenon for the urban environment. In addition, any activities or public events at urban public space become vital part of city design which is based on the needs and interests. Commonly, public spaces are useful as a place for playground, square or park, neighbourhood space, as a gathering space to promote sense of community and social interaction. Besides it serves as gathering space, public space could also play important roles in matters of the public and urban areas.

Rosly and Abdul Rashid (2013) pointed out that by introducing the revitalization of urban public space in GTWHS will creatively generate new ideas, knowledge and impetus. Furthermore, the provision of public space will improve the aesthetic quality and features as well as develop city's economic thereby it can meet the users' needs and demands. From the research findings, the effects of public space on urban development have been highlighted. Results from the quantitative analysis revealed that $70 \%$ of the findings indicated the effect of urban public space towards urban development. For example, urban public space would improve the urban environment, increase economic and tourism development, upgrade vitality, enhance city image, forms a public space culture and improve liveliness in urban development. In addition, in-depth interviews showed that pleasant and good 
organization and coordination are required between the departments and agencies in proposing revitalization strategies of public space. When urban public space functions smoothly, it can serve as a stage of urban life. Thus, urban public spaces are considered as the major public activities nodes within central part of George Town in order to improve urban development.

\subsection{Physical planning of public space}

According to Abdul Aziz (2012), the physical activity behaviour including type, duration and frequency are interconnected with physical environment and settings. Nasution et al., (2012) explained that in creating safe movement system and human comfort in public space, the physical dimension should be clear and easy access in order to encourage users either locals or foreigners to get to urban park. Regarding the successful places, public space plays an important role as physical component in developing revitalization strategies. This is supported by study in exploring the definition of the place to clarify the planning process through people's perceptions and behaviour (Wan Ismail \& Said, 2015).

In planning urban public space in GTWHS, it should highlight the cultural setting, historical site (Nik Mohammad, Saruwono, Said and Wan Hairi, 2013), human needs and natural context to maintain the place. Meanwhile, Kusumowidagdo et al. (2015) stated that all the valueable components in heritage site should be preserved and cannot be destroyed in order to create sense of place so that future generation can learn, recognize and experience it by looking the physical components at the public space. This is supported by Nik Mohammad et al. (2013), remarked that place could play a critical role as space between users and environment setting for revitalization strategies.

Table 2: Descriptive analvsis of perceptions on facilities and street furniture in public space

\begin{tabular}{llll}
\hline Perception & Minimum & Maximum & Mean \\
\hline $\begin{array}{l}\text { Pedestrian walkways fully connected } \\
\text { Clean and good condition of public }\end{array}$ & 2 & 5 & 4.1150 \\
toilet & 1 & 5 & 3.5150 \\
$\begin{array}{l}\text { Sufficient parking space } \\
\text { Comfort and safety gazebo }\end{array}$ & 1 & 5 & 2.8500 \\
$\quad \begin{array}{l}\text { Comfortable design and suitable } \\
\text { benches }\end{array}$ & 1 & 5 & 1.9000 \\
$\begin{array}{l}\text { Appropriate location, design and } \\
\text { maintenance aspects of dustbins }\end{array}$ & 1 & 5 & 3.8050 \\
$\begin{array}{l}\text { Sufficient lighting for safety and } \\
\text { security }\end{array}$ & 1 & 5 & 3.7575 \\
$\begin{array}{l}\text { Informative signage } \\
\text { Safe and attractive playground }\end{array}$ & 1 & 5 & 3.6850 \\
$\begin{array}{l}\text { Aesthetically pleasing with natural } \\
\text { features }\end{array}$ & 1 & 5 & 3.7075 \\
\hline
\end{tabular}

Other review focused on the physical aspect of public space planning which is landscape 
that consists of active and passive green; soft and hardscape; and street furniture (Samadi et al., 2012). In built environment, the important elements are green area and landscape which can create a place as a space for social communication to interact to each other and to feel the authenticity of public space in heritage site. As highlighted by Namin et al. (2013), the greater social engagement and interaction among public space users can be improved through landscape features while enjoying the peaceful landscapes ambiance. The physical setting of place should be highlighted in designing public spce including all design aspects and beautification of the landscape. Besides, the comfortable environment at urban public space can improve quality of life through the landscape setting as well as will give a boost to urban life and at the same time being as a catalyst for social interaction (Nasution et al., 2012).

Based on the questionnaire survey through quantitative analysis, half of the respondents expressed the lack of natural features at the study area. In addition, it was found the shodddy landscaping works is unsafe for children to use the space. Table 2 above shows the findings that reveals the less functioning of public space facilities due to lack of natural features such as bicycle trail and pedestrian walkway interconnected with the air quality and climate of the urban environment. This is supported by Ja'afar et al. (2013) stated that the physical planning not only based on the soft landscape feature at public space, but encompassed the hard landscape features and street furnitures such as bicycle racks, signage, lighting and benches. Following this, Zendehdelan, Pouyanfar and Ahmad (2013) pointed out the design quality of landscaping at public space should emphasize the space environment, roads circulation, entrances in order to create sense of place and to form continuity in public space. In other words, the landscape elements can portray the identity of study area in GTWHS.
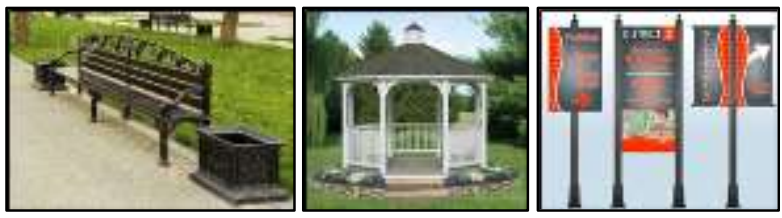

Figure 4: Examples of street furniture in public space

Several studies investigated the human needs and comfort which related to access and linkage at public space. This aspect is significant to ensure users' convenience whereby it improves access and connectivity to all facilities in the public space. This view was supported by Rosly et al. (2013), stated that the public space development should highlight the comfort of users, interconnected with the urban fabric environment in order to create continuity between the public realm, pedestrian networks and green spaces. Thus, this means that the comfort and safety features should be emphasized in physical planning of public space thereby users will spontaneously and continuously use the public space without coercion. Figure 4 above shows the street furniture in public space such as benches, gazebo and signage which can create interesting urban environment.. 


\subsection{Management approach in public space}

The purpose of local authorities developing public space is to provide an opportunity for people to benefit from them and to be close to nature (Shuib, Hashim and Mohd Nasir, 2015). From this view, the proper strategies and actions are very essential to enhance the awareness, consciousness and promote respect in using public spaces by ensuring them always clean, suggesting new activities and events (Namin et al., 2013). The service of public space by the management party can be enhanced through productive and integrated management; good and exciting promotion thereby it can increase the number of users coming to the public space. The maintenance and cleanliness aspect should be improved and regain awareness to avoid abandoned and isolated area. All respondents from the qualitative analysis suggested that good cooperation and comprehensive management between government and agencies are very important in terms of responsibility and coordination either directly or indirectly involve in management of urban public space at GTWHS.

In other context, the management of public space should also highlights on the public facilities to meet the needs and satisfaction of users. So, the management party should have the ability to predict the types and levels of users' needs in order to meet the different needs and demand of users. Besides, in implementing revitalization strategies, there are initiatives for funding management (Rosly et al., 2013). This initiative is very useful and beneficial in monitoring the management and implementation at public space in GTWHS which involve matters related on public transport, promotion, public awareness, branding, research, tourism, safety, impact studies and provide advisory services pertaining to heritage sites (GTWHI, 2014). Therefore, all the related agencies should be interconnected and have good collaboration and cooperation in revitalization strategies of public space in GTWHS.

\subsection{Conclusion}

Public space often offers great benefits for users in order to enhance quality of urban life. The study on how revitalization strategies provide benefits for urban public space planning is fundamental and should be emphasized eventhough there were numerous efforts and action have been applied to ensure the public space characteristics achieve the users' needs and demand. In preparing revitalization strategies of urban public space in GTWHS, the local residents and tourists play a vital role to ensure the benefits of public space were delivered effectively and comprehensively.The research instruments such as literature review, questionnaire surveys, in-depth interviews and public meetings were applied in this study to gain more precise views and perceptions from the users.

Following this, several recommendations have been determined from the discussion and findings of the quantitative and qualitative analysis in this study. In line with the aim and objectives, the recommendations have been proposed to meet the requirements of the study accordingly. Generally, all the recommendations in this study are also considering the guidelines and policy in the planning aspect. Hence, the aim of this study is to assess and improve revitalization of urban public space in core zone, GTWHS. In addition, this study also 
has described on how revitalization strategies assist towards successful urban public space. This kind of study could be very useful for for planners, local authorities and other management parties to determine the success of the public space. In the broader context, this study is applicable and beneficial to enhance and improve the planning and management of public space in order to meet the users' needs and demands.

\section{Acknowledgement}

The authors would like to acknowledge the Research Management Institute of UniversitiTeknologi MARA. The highest appreciation goes to the co-researchers who guided and supported for preparing this paper.

\section{References}

Abdul Aziz, N. A. (2012). Green space use and management in Malaysia. Forest and Landscape Research, 51(2012), 1-71.

Abdul Majeed, H. (2012). Urban regeneration: The case of Penang, Malaysia putting policy into practice. Retrieved from http://siteresources.worldbank.org/INTCHD/Resources/MalaysiaBBL2.pdf

Abdul Rahman, N., Shamsuddin, S., and Ghani, I. (2015). What makes people use the street?: Towards a liveable urban environment in Kuala Lumpur city centre. Procedia - Social and Behavioral Sciences, 170(2015), 624-632.

Bagwell, S., Evans, G., Witting, A., and Worpole, K. (2012). Public space management report to the intercultural cities research programme. Retrieved from https://rm.coe.int/CoERMPublicCommonSearchServices/DisplayDCTMContent?documentld=09000016803009c0

Couch, C., Sykes, O., \&Borstinghaus, W. (2010). Thirty years of urban regeneration in Britain, Germany and France: The importance of context and path dependency. Progress in Planning, 75(2011), 1 - 52.

Doratli, N., Hoskara, S. O., and Fasli, M. (2004). An analytical methodology for revitalization strategies in historic urban quarters: A case study of the Walled City of Nicosia, North Cyprus. Cities, 21(4), 329-348.

Farzaneh, M. (2011). Urban Development Planning, Regeneration and Public Participation: A Comparison Between the UK and Iran. Newcastle University, United Kingdom.

George Town World Heritage Incorporated. (2014). George Town Special Area Plan. Retrieved from http://www.gtwhi.com.my/resource/important-documents/george-town-special-area-plan.html

Ja'afar, N. H., Sulaiman, A. B., and Shamsuddin, S. (2012). The contribution of landscape features on traditional streets in Malaysia. Procedia - Social and Behavioral Sciences, 50(2012), 643-656.

Kurniawati, W. (2012).Accommodative Study of Public Space for Marginalized People. Asian Journal Of Environment-Behaviour Studies, 3(10), 1-10.

Kusumowidagdo, A., Sachari, A., and Widodo, P. (2015).Visitors' perception towards public space in shopping center in the creation sense of place. Procedia - Social and Behavioral Sciences, 184(2015), 266-272. 
Md. Sakip, S. R., Mt Akhir, N., and Omar, S. S. (2015).Determinant factors of successful public parks in Malaysia. Procedia - Social and Behavioral Sciences, 170(2015), 422-432.

Namin, E. R., Najafpour, H., and Lamit, H. (2013). Public places and spaces and social urban interaction (A case study of Johor Bahru, Malaysia). International Journal of Current Engineering and Technology, 3(2), 281-291.

Nasution, A. D., and Zahrah, W. (2012).Public open space privatization and quality of life, case study Merdeka Square Medan. Procedia - Social and Behavioral Sciences, 36(2012), 466-475.

Nasution, A. D., and Zahrah, W. (2015). The Space is not ours, the life of public open space in gated community in Medan, Indonesia. Procedia - Social and Behavioral Sciences, 202(2015), 144-151.

Nik Mohammad, N. M., Saruwono, M., Said, S. Y., and Wan Hariri, W. A. H. (2013). A sense of place within the landscape in cultural settings. Procedia - Social and Behavioral Sciences, 105(2013), 506-512.

Project for Public Spaces and Metropolitan Planning Council. (2008). What makes a place great? A neighborhood guide to placemaking in Chicago. Retrieved January 4, 2016, from http://www.placemakingchicago.com/about/great.asp

Qamaruz-Zaman, N., Samadi, Z., and Nik Azhari, N. F. (2013). Under the flyovers of Kuala Lumpur: User centered activities in leftover spaces. Journal of Asian Behavioural Studies, 3(10), 89-103.

Rosly, D., and Abdul Rashid, A. (2013). Revitalizing urban development in Malaysia through the implementation of urban regeneration programme. Perspective on Urban Redevelopment, 1-20.

Rostami, R., Lamit, H., Khoshnava, S. M., and Rostami, R. (2016). Successful public places: A case study of historical Persian gardens. Urban Forestry and Urban Greening, 15(2016), 211-224.

Said, S. Y., Aksah, H., and Ismail, E. D. (2013). Heritage conservation and regeneration of historic areas in Malaysia. Procedia - Social and Behavioral Sciences, 105(2013), 418 - 428.

Samadi, Z. and Yunus, R. M. (2011). Urban heritage streets' revitalising attributes. Asian Journal of EnvironmentBehaviour Studies, 3(7), 69-78.

Samadi, Z., \&MohdYunus, R. (2012). Physical and spiritual attributes of urban heritage street's revitalization. Procedia - Social and Behavioral Sciences, 36(2012), 342-349.

Hajmirsadeghi, R. S., Shamsuddin. S., \&Foroughi, A. (2012). The impact of physical design factors on the effective use of public squares. International Journal of Fundamental Psychology \& Social Sciences, 2(3), 49-56.

Shuib, K. B., Hashim, H., and Mohd Nasir, N. A. (2015). Community participation strategies in planning for urban parks. Procedia - Social and Behavioral Sciences, 168(2015), 311-320.

Wan Ismail, W. A., and Said, 1. (2015). Integrating the community in urban design and planning of public spaces: A review in Malaysian cities. Procedia - Social and Behavioral Sciences, 168(2015), 357-364.

Zendehdelan, A., Pouyanfar, E., and Ahmad, H. (2013). The perception of the sense of place in public spaces' quality through the five senses: "Case study of Naqsh-e-Jahan Square, Isfahan, Iran". Journal of Basic and Applied Scientific Research, 3(2), 1012-1020.

Zhai, B., and Ng, M. K.(2013). Urban regeneration and social capital in China: A case study of the Drum Tower Muslim District in Xi'an. 